Marquette University

e-Publications@Marquette

Psychology Faculty Research and Publications

Psychology, Department of

8-1-2013

\title{
Initial Development and Validation of the Mexican Intercultural Competence Scale
}

Lucas Torres

Marquette University, lucas.torres@marquette.edu

Accepted version. Journal of Latina/o Psychology, Vol. 1, No. 3 (August 2013): 171-181. DOI. (C) 2013 American Psychological Association. Used with permission.

This article may not exactly replicate the final version published in the APA journal. It is not the copy of record. 


\title{
Initial Development and Validation of the Mexican Intercultural Competence Scale
}

\author{
Lucas Torres \\ Psychology Department, Marquette University \\ Milwaukee, WI
}

\begin{abstract}
The current project sought to develop the Mexican Intercultural Competence Scale (MICS), which assesses group-specific skills and attributes that facilitate effective cultural interactions, among adults of Mexican descent. Study 1 involved an Exploratory Factor Analysis $(N=184)$ that identified five factors including Ambition/Perseverance, Networking, the Traditional Latino Culture, Family Relationships, and Communication. In Study 2, a Confirmatory Factor Analysis provided evidence for the 5 -factor model for adults of Mexican origin living in the Midwest $(N=341)$ region of the U.S. The general findings are discussed in terms of a competence-based formulation of cultural adaptation and include theoretical and clinical implications.
\end{abstract}

Keywords: Mexican intercultural competence, acculturation, cultural adaptation, scale development

Latinos living in the United States continue to grow at exponential rates with individuals of Mexican descent constituting the majority of this group (Pew Hispanic Center, 2012). This changing demographic profile has increased the need to better understand the process by which individuals navigate different cultural contexts. 
Competence involves the effectiveness of an individual's adaptation to an environment and refers to the success in the developmental tasks expected of individuals given their particular context (Masten \& Curtis, 2000). This conceptualization is inherently multidimensional and presumes that a cultural framework contributes to the elements of competence. As a way of integrating culture and competence, seminal work by Ogbu (1981) identified a native theory of success and defined it as a shared cultural knowledge regarding the group-specific competencies and strategies to accomplish valued cultural tasks. That is, ethnic minority groups define culturally-important areas or tasks and develop skills that correspond to the practices, beliefs, and values of the traditional culture.

Generally speaking, acculturation, or the changes that occur when individuals come into contact with two or more cultural groups (Berry, 2003), has been the focus of much of the empirical research examining adapting to a new culture. However, researchers have noted that a major limitation of the acculturation research has been its relatively narrow focus on language and cultural practices that may only serve as proxies for cultural adaptation (Schwartz, Unger, Zamboanga, \& Szapocznik, 2010). As such, competence within a cultural context plays a critical role in the conceptualization of negotiating new and different cultures (Padilla \& Perez, 2003). Competence-based formulations of cultural adaptation emphasize that a mastery of particular sets of functional skills is key to psychological well-being and fulfillment of societal roles (LaFromboise et al., 1993). Intercultural competence concerns group-specific instrumental skills and attributes necessary to engage in effective and appropriate cultural interactions within multiple contexts. Broadly speaking, intercultural competence represents the effective management of interactions between people who have different affective, cognitive, and behavioral orientations to the world (Spitzberg \& Changnon, 2009). Intercultural competence, also referred to as intercultural effectiveness or intercultural adaptation, has been largely examined in cross-cultural interactions among individuals living outside of the U.S., such as university students studying abroad, Peace Corp workers, and diplomats, etc. Intercultural competence provides a broad framework to understand the underlying behaviors, attitudes, and worldviews that promote successful cultural interactions, which can incorporate models of acculturation (Spitzberg \& Changnon). However, participating in 
different cultures or acculturation level alone may not be indicative of competence within those environments (David, Okazaki, \& Saw, 2009).

The empirical research examining biculturalism and/or bicultural competence has sought to understand the process of living in different cultures within an acculturation model (Mistry \& Wu, 2010).

Biculturalism involves a proficiency in two or more cultures and the integration of cultural elements into a unique blend (Benet-Martinez \& Haritatos, 2005; Padilla, 2006). Bicultural individuals have been described as individuals who have internalized two cultures to the extent that both are salient within them (Hong, Morris, Chiu, \& BenetMartinez, 2000). LaFromboise, Coleman, and Gerton (1993) examined bicultural competence, which they argue emerges from an alternation acculturation model. They identified several distinct dimensions including Knowledge of Cultural Beliefs and Values or an awareness of the cultures' everyday practices, Positive Attitudes Toward Groups or having positive regard for the cultural groups, Bicultural Efficacy or the belief one can function effectively within different cultural groups, Communication Ability or the capacity to express ideas to members of a given culture, Role Repertoire or the range of appropriate behaviors and roles, and Social Groundedness, or established social networks.

Given this conceptualization, biculturalism is typically thought of as a process that occurs among individuals who are U.S.-born or of later generations. However, individuals navigating two cultures, regardless of nativity or generation status, can do so by endorsing 1) a preference to synthesize features of both cultural elements into a unique blend or 2) a preference for keeping the traditional and the mainstream cultural knowledge and attributes separate (Schwartz et al., 2010). Along these lines, some Latinos negotiating cultural contexts may consider themselves accountable to only one culture while others may feel responsible for both sets of cultural expectations (David et al., 2009).

For the purpose of the current study, intercultural competence addresses the functional skills and attributes that facilitates successful cultural interactions in both the mainstream U.S. and Latino cultures but does not assume that the internalization of two cultures occurs. That is to say, Latinos living in the U.S. have to negotiate different 
cultural contexts effectively regardless of whether they prefer a blended identity of cultures or consider themselves accountable to only one culture. The definition of competence and success is influenced by the context and cultural frame of reference by which they approach exchanges with the mainstream U.S. and Latino cultures. For example, the repertoire of skills and method by which an individual approaches a social situation is based on whether establishing network connections or maintaining supportive friendships is the valued outcome of that cultural contact.

A recent study identified the characteristics that Latino participants deemed necessary for intercultural competence (Torres, 2009). This study used qualitative semistructured interviews and a systematic ethnographic technique known as cultural consensus analysis with two separate samples of Latino adults. Fifteen Latino adults, the majority of which were of Mexican descent $(n=11)$, were asked to think about a Latino individual they consider "successful" in the U.S. and Latino cultures and to describe the characteristics and/or skills possessed by that individual. One emergent theme relating to effective cultural interactions in both the mainstream U.S. and Latino cultural contexts included Ambition to Succeed, or having realistic goals, aspirations, and a drive to achieve. This theme highlighted applying an active orientation to the adaptation process rather than a passive one that may include unrealistic expectations about living in the U.S. Communication skills, or the effective communication of thoughts and ideas, was also identified but was described beyond language acquisition. Participants also indicated that Establishing Connections was a key aspect of intercultural competence but differentiated Relationship Building, or the willingness to develop interpersonal connections with family and others, as important within the mainstream U.S. context while Networking, or knowing people who have been successful and establishing contacts in the community, was essential within the Latino culture. The former illustrated the notion that cultural adaptation occurs through interpersonal relationships and may serve a source of emotional support while the latter was indicative of building social capital. Other themes included Perseverance, or the persistence and willpower to continue even through challenging circumstances and Maintenance of Traditional Latino Culture, or actively maintaining one's culture of origin.

Journal of Latina/o Psychology, Vol 1, No. 3 (August 2013): pg. 171-181. DOI. This article is @ American Psychological Association and permission has been granted for this version to appear in e-Publications@Marquette. American Psychological Association does not grant permission for this article to be further copied/distributed or hosted elsewhere without the express permission from American Psychological Association. 
Participants endorsing this last theme spoke of keeping up with cultural traditions, values, and pride as key for success.

The themes that emerged from the qualitative interviews were then examined via cultural consensus analysis among a separate group of 46 adults of Mexican descent distributed evenly across gender, nativity status, and annual income (Torres, 2009). Cultural consensus analysis measures the extent to which there is agreement on the definition of a cultural construct among participants (Dressler, Balieiro, \& dos Santos, 1998). This technique tests for a shared pool of knowledge that is distributed across groups. The findings of the Torres (2009) study showed that a common cultural model of Mexican intercultural competence existed among the participants providing evidence that the attributes identified by the qualitative interviews constituted intercultural competence as understood by this group of individuals.

The components of intercultural competence outlined by Torres (2009) are congruent with extant research. For instance, the themes of Ambition to Succeed and Perseverance suggests that effective negotiation of the U.S. and Latino cultures involves having realistic expectations and goals regarding the adaptation process, a determination to achieve, as well as the willpower to overcome environmental barriers. Tyler (2001) indicated that competent individuals view themselves as active agents within their environment and develop self-efficacy or styles of living that facilitate negotiating the detrimental effects of stressful life events. Similarly, LaFromboise et al. (1993) suggested that bicultural efficacy, or the confidence to live effectively within groups, contributed to the development of communication skills, accomplishment of cultural roles, and the management of acculturative stressors.

LaFromboise and colleagues (1993) similarly identified the themes of Communication and Networking. Developing an enhanced social network has been thought to increase an individual's cultural capital and sense of well-being (Bacallao \& Smokowski, 2009). Recent work has indicated that establishing social networks served to buffer the relationship between minority stress and depressive symptoms among a group of ethnic minority undergraduate students (Wei et al., 2010). Further, Bacallao and Smokowski (2009) reported that, based

Journal of Latina/o Psychology, Vol 1, No. 3 (August 2013): pg. 171-181. DOI. This article is @ American Psychological Association and permission has been granted for this version to appear in e-Publications@Marquette. American Psychological Association does not grant permission for this article to be further copied/distributed or hosted elsewhere without the express permission from American Psychological Association. 
on interviews with Latino adolescents and their parents, identification with or maintenance of traditions of the culture of origin, an orientation to the family, along with development of bilingual skills were key to living between two cultures.

In summary, the process of living in multiple cultural contexts has been examined primarily within an acculturation framework (i.e., biculturalism/bicultural competence). The notion of intercultural competence integrates competence/resilience and cultural models with the former providing the structure of functioning while the latter elucidates the content (Jensen, 2011). This can be accomplished by first determining the characteristics that define success and the cultural attributes and skills that correspond to an individual's environment. Unfortunately, a valid and reliable measure that assesses the unique features of Latino intercultural competence does not exist. The overall objective of the current project was to develop and validate the Mexican Intercultural Competence Scale (MICS) with adults of Mexican descent. Study 1 entails an Exploratory Factor Analysis (EFA) of MICS items derived from the emergent themes described by Torres (2009). Study 2 involves Confirmatory Factor Analyses (CFA) with a sample of adults of Mexican descent.

\section{Study 1: Exploratory Factor Analysis}

\section{Method}

\section{Participants}

Study 1 included 184 adult volunteers who self-identified as Mexican, Mexican-American, or Chicano. These participants were recruited from local Latino-serving organizations and community events from a moderately-sized Midwestern city. This group averaged approximately 41 years of age $(S D=14.90$, Range $=18-80)$ and was comprised of mostly women $(69 \%, n=160)$. The mean number of years lived in the U.S. for Study 1 participants was 36.39 (SD = 17.85; Range $=1-80$ ). As an indicator of socioeconomic status (SES), approximately $17 \%$ of the sample $(n=30)$ reported an annual family/household income of $\$ 20,000$ or less, $39 \%(n=68)$ indicated earning between $\$ 20,000$ and $\$ 50,000$, while $44 \%(n=77)$ stated an 
income of $\$ 50,000$ or more. The median income for Latinos in the county from which participants were recruited was $\$ 37,911$ (U.S. Census Bureau, 2009). In terms of education level, $21 \%(n=39)$ reported less than a high school education, $22 \%(n=41)$ indicated completing a high school degree or equivalent, $40 \%(n=73)$ stated having some college, while $17 \%(n=31)$ had attained a bachelor's degree or higher. Twenty percent of the sample $(n=37)$ was currently enrolled as a student.

\section{Materials}

\section{Mexican Intercultural Competence}

The items comprising the Mexican Intercultural Competence Scale (MICS) are based on the research by Torres (2009) which used separate methodologies, including qualitative strategies and cultural consensus analysis, to generate the features and cultural model of Latino intercultural competence. Torres (2009) found a shared knowledge base regarding the attributes needed for Latinos to successfully navigate the U.S. and Latino cultures, across socioeconomic and generational levels. As mentioned previously, the themes that emerged from the qualitative analyses included Ambition, Perseverance, Relationship Building, Networking, the Traditional Latino Culture, and Communication. Torres (2009) generated a list of 34 items representing these themes. The content of the items were derived from the qualitative transcripts. The items created were thought to be the most descriptive and/or appropriate for the specific theme. For the current project, an independent team of research assistants reviewed the 34-item version of the MICS for content and readability. The team rated several statements as problematic because they were repetitive or poorly worded. Removing these items did not significantly change the number of items per theme, therefore, the scale was condensed to 26 items. The 26 -item MICS (see Table 1 ) used in Study 1 involved a 5-point Likert scale ranging from 0 (not at all important) to 4 (very important). 
NOT THE PUBLISHED VERSION; this is the author's final, peer-reviewed manuscript. The published version may be accessed by following the link in the citation at the bottom of the page.

Table 1. Factor Loadings of Principal Component Exploratory Factor Analysis With Equamax Rotation ( $\mathrm{N}=184)$.

\begin{tabular}{|c|c|c|c|c|c|}
\hline Scale Items & $\begin{array}{c}\text { Ambition/ } \\
\text { Perseverance }\end{array}$ & Networking & Family & Communication & $\begin{array}{c}\text { Traditional } \\
\text { Culture }\end{array}$ \\
\hline $\begin{array}{l}\text { Having a strong } \\
\text { desire to be } \\
\text { successful. }\end{array}$ & .71 & .20 & .22 & .23 & .13 \\
\hline $\begin{array}{l}\text { Striving for } \\
\text { more, always } \\
\text { looking to be } \\
\text { more successful. }\end{array}$ & .73 & .20 & .15 & .03 & .33 \\
\hline $\begin{array}{l}\text { Having strong } \\
\text { will power or } \\
\text { determination. }\end{array}$ & .76 & .15 & .02 & .19 & .22 \\
\hline $\begin{array}{l}\text { Knowing, deep } \\
\text { down, that you } \\
\text { are going to } \\
\text { make it. }\end{array}$ & .72 & .15 & .36 & .22 & .12 \\
\hline $\begin{array}{l}\text { Not giving up or } \\
\text { quitting even } \\
\text { when things are } \\
\text { not going the } \\
\text { way you are } \\
\text { expecting. }\end{array}$ & .81 & .10 & -.08 & .19 & .12 \\
\hline $\begin{array}{l}\text { To continue to } \\
\text { do the extra } \\
\text { work, even } \\
\text { though } \\
\text { circumstances } \\
\text { are against you. }\end{array}$ & .58 & .22 & .20 & .17 & .19 \\
\hline $\begin{array}{l}\text { Meeting new } \\
\text { people and } \\
\text { seeing how } \\
\text { those people can } \\
\text { help you. }\end{array}$ & .06 & .83 & .18 & .06 & .09 \\
\hline $\begin{array}{l}\text { Connecting with } \\
\text { people so you } \\
\text { can help them } \\
\text { and they can } \\
\text { help you. }\end{array}$ & .18 & .82 & .15 & .15 & .12 \\
\hline $\begin{array}{l}\text { Networking with } \\
\text { people who have } \\
\text { been successful. }\end{array}$ & .27 & .66 & .05 & .28 & .24 \\
\hline $\begin{array}{l}\text { Creating } \\
\text { networks or } \\
\text { connections with } \\
\text { others. }\end{array}$ & .12 & .72 & .18 & .29 & .22 \\
\hline $\begin{array}{l}\text { Keeping in touch } \\
\text { with everyone in } \\
\text { the family. }\end{array}$ & .02 & .11 & .86 & -.01 & .20 \\
\hline
\end{tabular}

Journal of Latina/o Psychology, Vol 1, No. 3 (August 2013): pg. 171-181. DOI. This article is @ American Psychological Association and permission has been granted for this version to appear in e-Publications@Marquette. American Psychological Association does not grant permission for this article to be further copied/distributed or hosted elsewhere without the express permission from American Psychological Association. 
NOT THE PUBLISHED VERSION; this is the author's final, peer-reviewed manuscript. The published version may be accessed by following the link in the citation at the bottom of the page.

\begin{tabular}{|c|c|c|c|c|c|}
\hline Scale Items & $\begin{array}{c}\text { Ambition/ } \\
\text { Perseverance }\end{array}$ & Networking & Family & Communication & $\begin{array}{c}\text { Traditional } \\
\text { Culture }\end{array}$ \\
\hline $\begin{array}{l}\text { Having strong } \\
\text { family values. }\end{array}$ & .21 & .09 & .86 & .13 & .06 \\
\hline $\begin{array}{l}\text { Getting along } \\
\text { with family. }\end{array}$ & .01 & .19 & .73 & .25 & .05 \\
\hline $\begin{array}{l}\text { Being able to } \\
\text { relate to all sorts } \\
\text { of people. }\end{array}$ & .10 & .41 & .06 & .67 & .23 \\
\hline $\begin{array}{l}\text { Being able to } \\
\text { express yourself } \\
\text { in English and } \\
\text { Spanish. }\end{array}$ & .13 & .10 & .14 & .87 & .14 \\
\hline $\begin{array}{l}\text { Being able to } \\
\text { communicate } \\
\text { well in English. }\end{array}$ & .21 & .12 & .18 & .83 & .05 \\
\hline $\begin{array}{l}\text { Embracing your } \\
\text { culture for } \\
\text { motivation. }\end{array}$ & .24 & .12 & .01 & .08 & .84 \\
\hline $\begin{array}{l}\text { Identification } \\
\text { with one's past } \\
\text { or roots. }\end{array}$ & .10 & .10 & .25 & .05 & .85 \\
\hline $\begin{array}{l}\text { Maintaining the } \\
\text { cultural } \\
\text { practices, } \\
\text { holidays, and/or } \\
\text { language of your } \\
\text { country. }\end{array}$ & .09 & .18 & .08 & .25 & .71 \\
\hline
\end{tabular}

\section{Acculturation}

The Brief- Acculturation Rating Scale for Mexican Americans-II (B-ARSMA-II; Cuellar, Bastida \& Braccio, 2004) is an abbreviated 12item version of the original 30 item measure. This self-report survey uses a 5-point Likert scale ranging from 1 (not at all) to 5 (extremely often or almost always) and asks questions pertaining to language preference and identification with the Latino and Anglo culture. The BARSMA-II contains 6 items for the Anglo Orientation Score (AOS) and 6 items for the Mexican Orientation Score (MOS) which can be calculated via mean scores to assess these dimensions of acculturation. The B-ARSMA-II has been used with Latino adolescents and adults (Bauman, 2005; Cuellar et al., 2004; Kasirye et al., 2005). Internal consistency coefficients for the MOS have been reported at .83 while the AOS has been .88 (Cuellar et al., 2004). Participants' calculated Cronbach's alphas were .89 for the MOS and .75 for the AOS.

Journal of Latina/o Psychology, Vol 1, No. 3 (August 2013): pg. 171-181. DOI. This article is (C) American Psychological Association and permission has been granted for this version to appear in e-Publications@Marquette. American Psychological Association does not grant permission for this article to be further copied/distributed or hosted elsewhere without the express permission from American Psychological Association. 
NOT THE PUBLISHED VERSION; this is the author's final, peer-reviewed manuscript. The published version may be accessed by following the link in the citation at the bottom of the page.

\section{General Competence}

The Behavioral Attributes of Psychosocial Competence Condensed scale (BAPC-C; Zea, Reisen, \& Tyler, 1996) is a self-report scale that consists of 13 forced-choice items. This measure is an abbreviated version of the original 36-item BAPC developed by Tyler (1978). The BAPC-C assesses an individual's general style of proactive competent coping. The range of possible scores is from 0 to 13 with high scores indicating increased competence. Zea and colleagues (1996) demonstrated adequate internal consistency, in the form of Cronbach's alpha, for Latinos (.76). The coefficient alpha for the current study was .72 .

\section{Procedure}

Potential participants were approached at various local Latinoserving organizations and community events at which point they were given a brief description of the project, including confidentiality and anonymity of the survey. Those who gave a verbal consent were asked to complete a packet of questionnaires including the MICS, B-ARSMAII, BAPC-C, and a background information form. The instruments were counterbalanced to minimize potential order effects. Questionnaires were available in Spanish and English allowing participants to complete the materials in their language of preference. On average, participants completed the questionnaires in 30 to 45 minutes. The majority of the sample (84\%) chose to fill out the questionnaires in English.

Participants were compensated with a $\$ 10$ gift card upon completion of the survey. The study was conducted in compliance with the host institution's Internal Review Board.

\section{Results}

In order to determine the structure of the scale a principal component analysis with an equamax rotation was conducted on the 26 items. An equamax rotation was conducted in order to maintain orthogonality between the components. There were 184 cases in the sample. Five components with eigenvalues greater than 1.00 emerged. Examination of the components revealed that all of the components had multiple items with coefficients greater than .32 and were 
interpretable, so all 5 components were maintained (Tabachnick \& Fidell, 2007). Examination of the items revealed that 7 items crossloaded items, that is these items had coefficients greater than .32 on two components and the difference between these two loadings was less than .10. Given the desire to have independent components that did not have overlapping items, these items were removed from the scale. The final principal component analysis was conducted with the remaining 19 items, requesting five components. The five components accounted for $71.63 \%$ of the variance (see Table 1 ).

The first component accounted for $18.10 \%$ of the variance and was labelled Ambition/Perseverance (initial eigenvalue $=7.30$, rotated eigenvalue $=3.44$ ). This component included six items with primary loadings greater than .32. The second component accounted for $14.76 \%$ of the variance and was labelled Networking (initial eigenvalue $=1.94$, rotated eigenvalue $=2.81$ ). The third component accounted for $13.05 \%$ of the variance and was labelled Family Relationships (initial eigenvalue $=1.64$, rotated eigenvalue $=2.48$ ). The three items on this component consisted of items pertaining to building and maintaining relationships with family. The fourth component accounted for $12.94 \%$ of the variance and was labelled Communication (initial eigenvalue $=1.50$, rotated eigenvalue $=2.45$ ). The fifth component accounted for $12.77 \%$ of the variance and was labelled Traditional Latino Culture (initial eigenvalue $=1.24$, rotated eigenvalue $=2.43$ ) . Composite scores for each subscale were computed by averaging the items with primary loadings onto the component. The coefficient alphas for Ambition/Perseverance, Networking, Family Relationships, Communication, and Traditional Latino Culture were .91, .85, .80, .81, and .83 respectively. The five subscales were all positively intercorrelated, ranging from .31 to .56 (all ps <.01).

\section{Study 2: Confirmatory Factor Analyses}

\section{Method}

\section{Participants}

A group of 341 adults who identified as Mexican, Mexican American or Chicano participated in Study 2 and provided complete 
data. These individuals were recruited from Latino-serving organizations, churches, and community events in a moderately-sized Midwestern city. They averaged approximately 37 years of age ( $S D=12.04$, Range 18-80) and included mostly women $(64 \%, n=212)$. The average number of years lived in the U.S. was 18.61 ( $S D=15.25$; Range $=1-71)$. In terms of SES background, about half of the sample $(n=153)$ reported an annual family/household income of $\$ 20,000$ or less while $36 \%(n=124)$ indicated earning between $\$ 20,000$ and $\$ 50,000$. The median income for Latinos in the county from which participants were recruited was $\$ 37,911$, the same as described in Study 1 . In terms of education level, $45 \%(n=141)$ reported less than a high school education, 30\% $(n=96)$ indicated completing a high school degree or equivalent, $16 \%(n=50)$ stated having some college, while $9 \%(n=28)$ had attained a bachelor's degree or higher. A small portion of the sample $(13 \%, n=44)$ was currently enrolled as a student.

\section{Materials and Procedure}

The materials and procedures to Study 2 were the same as those described in Study 1. Participants were approached and informed of confidentiality and, upon giving verbal consent, completed the series of questionnaires. All participants had the option of completing the survey in either English or Spanish. Approximately $31 \%$ of participants completed the survey in English. The packet of questionnaires included a background information page, the MICS, the BAPC-C, and the B-ARSMA-II. The series of questionnaires required approximately 30 to 45 minutes for completion. Upon completion of the survey, the participants were compensated with a $\$ 10$ gift card. Approval from the host institution's Institutional Review Board was attained before data collection commenced.

\section{Results}

A confirmatory factor analysis using AMOS 17 was conducted for participants who had no missing data $(n=341)$. With the maximumlikelihood estimation method, the model was specified with five latent variables with the observed variables identified in the exploratory factor analysis. The latent variables were allowed to correlate. For 
identification purposes, the path of one measured variable for each latent variable was set to one (Arbuckle \& Wothke). In interpreting the models we examined the path estimates, root mean square error of approximation (RMSEA), $X^{2}$, standardized root mean square residual (SRMR), and several fit indices. Because the $X^{2}$ is influenced by the sample size we also looked at the $X^{2}$ to degrees of freedom ratio, where it has been suggested that a ratio of either 2 to 1 or 3 to 1 indicates an acceptable fit (Arbuckle \& Wothke, 1999; Ullman, 1996). The following are general "guidelines" to evaluate the fit: a RMSEA less than .05 indicates a "good fit" and less than .08 indicates an "acceptable fit," (McDonald \& Ho, 2002; Hu \& Bentler, 1999 suggest .06 for a "good fit"), SRMR less than .08 suggests an "excellent fit" (Hu \& Bentler, 1999), and goodness of fit statistics should generally be larger than .90 (Hu \& Bentler, 1999; McDonald \& Ho, 2002).

The model resulted in a $X^{2}(142)=413.39, p<.01\left(X^{2} / d f\right.$ ratio $=2.91, \mathrm{GFI}=.89, \mathrm{CFI}=.93, \mathrm{SRMR}=.04$, and $\mathrm{RMSEA}=.08$ ). All of the items had statistically significant loadings on the designated factor, indicating that the items were designated onto the correct factors (see Table 2). While the Chi-square was significant, the low Chi Square to Df ratio and relatively small residuals, and fit indices suggest that the five-factor structure was an adequate approximation of the data. The coefficient alphas (for the restricted sample consisting of only complete surveys) were as followed; Ambition/Perseverance $a=.89$, Networking $a=.86$, Traditional Latino Culture $a=.81$, Family Relationships $=.78$, and Communication $a=.79$. The high Chronbach coefficient alphas suggest internal reliability in the subscales. The subscales were all positively correlated (ranging from .41 to .78).

Table 2. Confirmatory Factor Analysis with standardized loadings of items onto designated latent variable $(\mathrm{N}=341)$.

\begin{tabular}{|c|c|c|}
\hline Scale Items & $\begin{array}{l}\text { Ambition/ } \\
\text { Perseverance }\end{array}$ & $\begin{array}{r}\text { Networking Family Communication Trad } \\
\text { Cultu }\end{array}$ \\
\hline $\begin{array}{l}\text { Having a strong desire } \\
\text { to be successful. }\end{array}$ & .85 & \\
\hline $\begin{array}{l}\text { Striving for more, } \\
\text { always looking to be } \\
\text { more successful. }\end{array}$ & .82 & \\
\hline
\end{tabular}


NOT THE PUBLISHED VERSION; this is the author's final, peer-reviewed manuscript. The published version may be accessed by following the link in the citation at the bottom of the page.

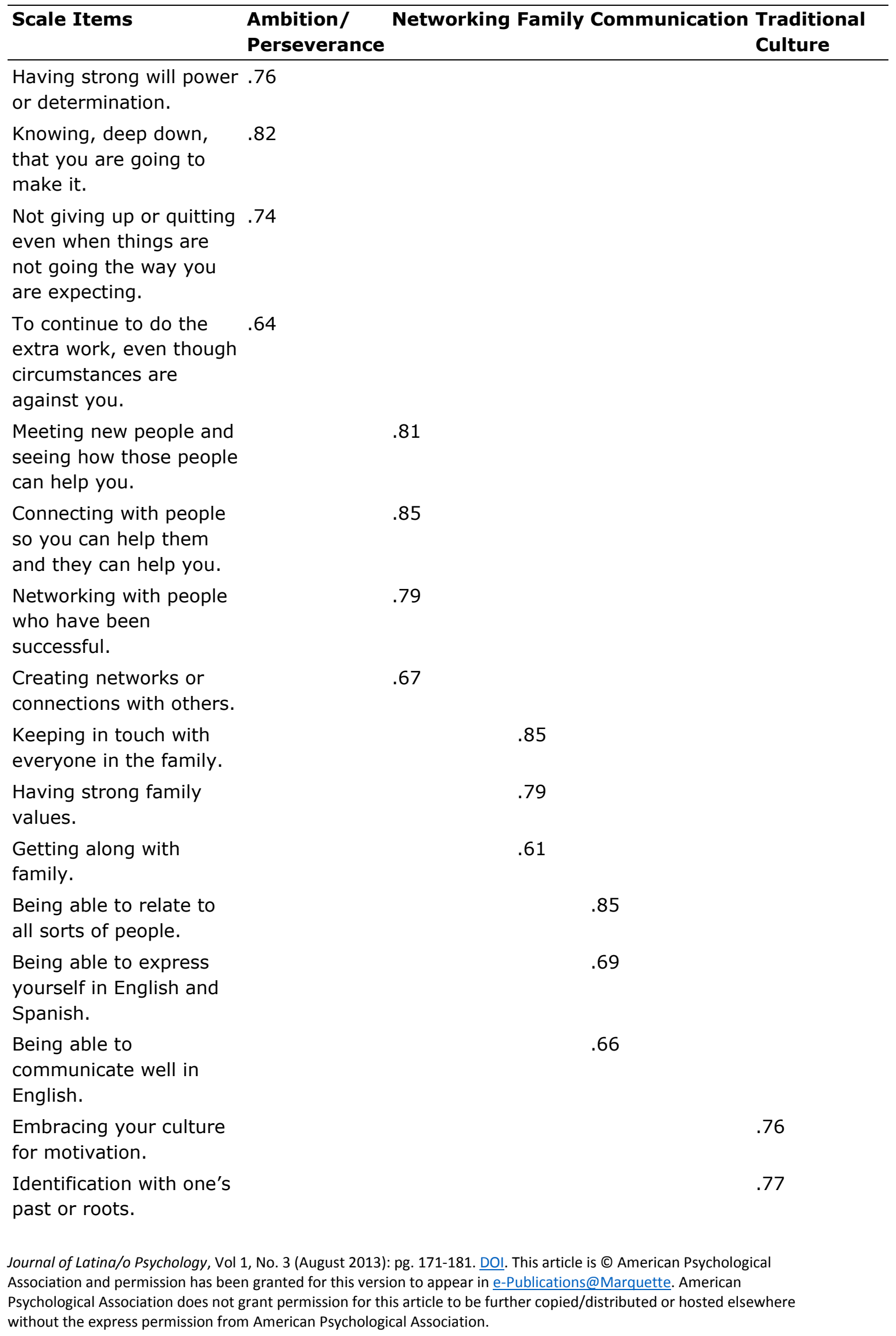


NOT THE PUBLISHED VERSION; this is the author's final, peer-reviewed manuscript. The published version may be accessed by following the link in the citation at the bottom of the page.

\begin{tabular}{llc}
\hline Scale Items & $\begin{array}{l}\text { Ambition/ } \\
\text { Perseverance }\end{array}$ & $\begin{array}{c}\text { Networking Family Communication Traditional } \\
\text { Culture }\end{array}$ \\
\hline $\begin{array}{l}\text { Maintaining the cultural } \\
\text { practices, holidays, }\end{array}$ & .77 \\
and/or language of your & & \\
country. & &
\end{tabular}

Table 3 shows the intercorrelations, means, and standard deviations of the study variables across Study 1 and Study 2 participants. A review of the zero-order correlations reveals that the MICS subscales, except for Ambition/Perseverance and Communication, were positively correlated to the Mexican orientation acculturation dimension providing some support for the construct validity of the MICS. Ambition/Perseverance and Communication were significantly correlated with AOS in the positive direction. The nonsignificant correlations between the majority of MICS subscales and demographic variables, namely age and years lived in the U.S., provides some indication of divergent validity. As further support for concurrent validity, the results revealed that the BAPC-C, a measure of general competence, was significantly and positively correlated to the MICS subscales.

\section{Table 3}

Means, standard deviations, and zero-order correlations of Study 1 and Study 2 participants $(\mathrm{N}=525)$.

1. Age

$\begin{array}{lllllllllll}1 & 2 & 3 & 4 & 5 & 6 & 7 & 8 & 9 & 10 & 11\end{array}$

2. Years lived in $\quad .62^{* * *} \quad--$

U.S.

3. MICS -

Ambition/

$\begin{array}{lll}-.01 & .01 & --\end{array}$

Perseverance

4. MICS -

Networking

5. MICS -

$-.08^{\dagger}-.14^{* *} .64^{* *} \quad--$

Traditional Culture

$\begin{array}{llll}-.01 & -.01 & .57^{* * *} .49^{* * *} & --\end{array}$

6. MICS - Family

$.05 \quad .02 \quad .52^{* * *} .43^{* * *} .44^{* * *}$

Relationships

7. MICS -

$-.04-.01 \quad .52^{* * *} .51^{* * *} .36^{* * *} .42^{* * *} \quad--$

Communication

8. MICS Total Mean $-.03-.04 \quad .88^{* * *} .82^{* * *} .72^{* * *} .67^{* * *} .72^{* * *} \quad--$

$\begin{array}{lllllllll}\text { 9. B-ARSMA-II - } & .10^{*} & .62^{* * *} & .10^{*} & .04 & .05 & .04 & .12^{* *} & .09^{*}\end{array}$

AOS

Journal of Latina/o Psychology, Vol 1, No. 3 (August 2013): pg. 171-181. DOI. This article is @ American Psychological Association and permission has been granted for this version to appear in e-Publications@Marquette. American Psychological Association does not grant permission for this article to be further copied/distributed or hosted elsewhere without the express permission from American Psychological Association. 
NOT THE PUBLISHED VERSION; this is the author's final, peer-reviewed manuscript. The published version may be accessed by following the link in the citation at the bottom of the page.

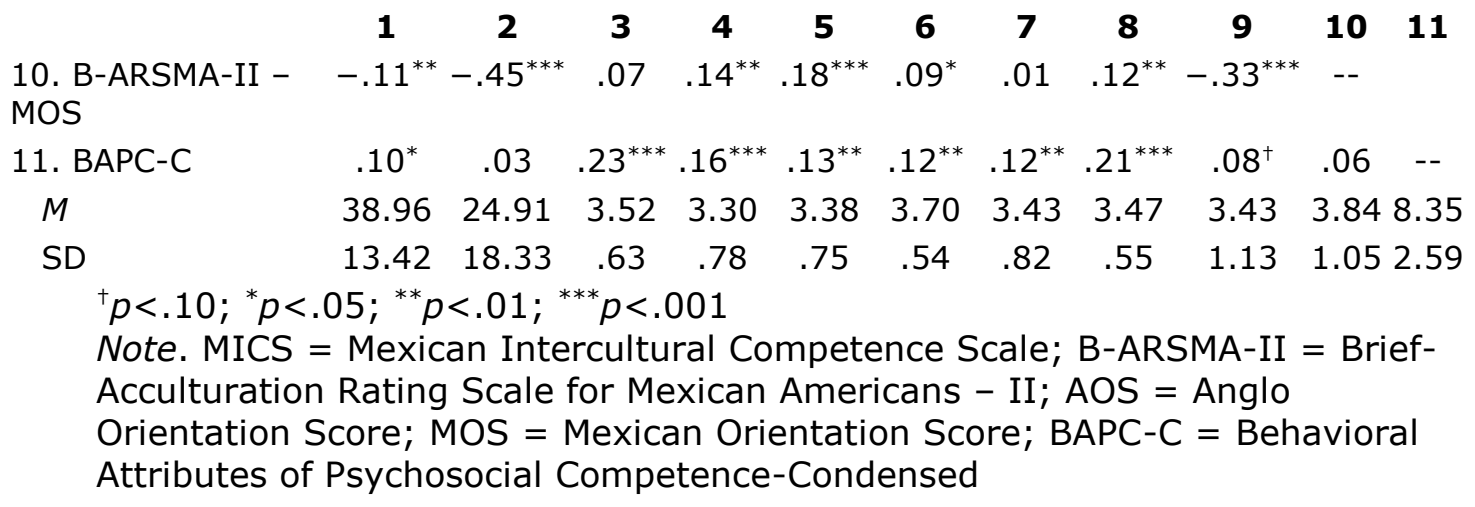

Additionally, independent samples $t$-tests were conducted to examine any potential group differences based on gender and nativity status. These analyses revealed no statistically significant differences across gender or nativity status for the MICS subscales or the BAPC-C. Significant differences emerged across AOS and MOS for nativity status [AOS $t(556)=-20.16, p<.001$; MOS $t(556)=12.92, p<.001$ ] indicating that, as expected, US-born individuals had higher AOS scores (US-born $M=4.26, S D=0.61$; foreign-born $M=2.78, S D=0.99$ ) but lower MOS scores (US-born $M=3.24, S D=1.10$; foreign-born $M=4.25, S D=0.76)$ than foreign-born participants. No statistically significant gender variations on acculturation scores were noted.

\section{General Discussion}

The main objective of the current project was to develop a new measure that assesses Mexican intercultural competence with a sample of adults of Mexican descent. To this end, the set of studies discussed provide evidence for the reliability and validity of the MICS. This research contributes to the emerging empirical literature on competence-based perspectives of cultural adaptation. Negotiating different cultures is a crucial developmental and cultural task that Latinos living in the U.S. contend with on a daily basis regardless of nativity status or generation level. The current project builds on the existing acculturation research and introduces novel concepts regarding the instrumental skills and attributes Mexican adults in the community deem necessary to succeed within the U.S. and Latino cultures. That is, examining Mexican intercultural competence expands current models of acculturation by highlighting the importance of engaging in an active or mastery orientation, a competence process, 
and identifying the cultural content or attributes in which such a process facilitates cultural interactions.

The exploratory and confirmatory factor analyses revealed that the construct of Mexican intercultural competence can be best conceptualized as containing five related factors, namely Ambition/Perseverance, Networking, the Traditional Latino Culture, Family Relationships, and Communication. These factors represent a set of characteristics that integrates domains or values from both the Mexican and the mainstream U.S. cultures. As partial support for convergent validity, the results showed that Ambition/Perseverance and Communication were correlated with the AOS while the MOS was significantly associated with Networking, the Traditional Latino Culture, and Family Relationships. These significant correlations suggest that Ambition/Perseverance and Communication are particularly important when interacting with the mainstream U.S. culture while Networking, Family Relationships, and the Traditional Latino Culture are key for successful transactions in the Latino community. Thus, unlike biculturalism, which assumes an internalization of characteristics for effective interactions in both cultures, the current project identifies the features of Mexican intercultural competence that best match the particular cultural context.

The significant correlations between the MICS subscales and the BAPC-C, a measure of general competence, provide evidence for the validity of the newly developed measure and suggest that the MICS is tapping into attributes of successful functioning within a cultural context. The nonsiginificant correlations between most of the MICS factors and demographic variables provide some indication of discriminant validity. Additionally, the lack of significant differences for the MICS subscales across gender and nativity status suggests that responses to these items are equivalent for men and women of Mexican descent as well as for U.S.-born and foreign-born individuals.

Ambition/Perseverance emerged as a feature of Mexican intercultural competence across the various samples but is not commonly mentioned within the empirical literature on acculturation. Ambition entails having realistic aspirations within the mainstream culture and a drive to succeed. This factor highlights the importance of self-mastery in the adaptation process and being an active participant

Journal of Latina/o Psychology, Vol 1, No. 3 (August 2013): pg. 171-181. DOI. This article is @ American Psychological Association and permission has been granted for this version to appear in e-Publications@Marquette. American Psychological Association does not grant permission for this article to be further copied/distributed or hosted elsewhere without the express permission from American Psychological Association. 
in the environment. Such an approach to cultural situations is consistent with a competence-based formulation that emphasizes a mastery-oriented perspective to negotiating life events and involves sound goal setting, taking initiative, and contributing to the surroundings (Tyler, 2001). Perseverance, or persisting through challenging situations, underscores the notion that Latinos anticipate experiencing difficult times and numerous barriers as they live within multiple cultures. This expectation may be suggestive of instances of discrimination and/or acculturative stressors experienced by many Mexican adults residing in the United States. Given the current national discourse on immigration policies in the U.S. and heightened scrutiny on border communities, it is plausible to say that individuals of Mexican descent are likely to experience significant discriminatory or stressful events. Taken together, Ambition/Perseverance represents a style of interacting primarily with the U.S. culture that facilitates success. The broad pattern of behaving has been thought to apply across cultures although the specific activities may vary by circumstances (Tyler, 2001). Mexican intercultural competence includes Communication skills as the ability to express thoughts and ideas remains a basic and essential part of effective cultural transactions.

As currently conceptualized, Networking provides a unique description of activities that are separate from social support and focus more on gaining social capital and interpersonal resources. Torres (2009) reported that the ability to establish effective networks was deemed particularly important when interacting within the Latino culture as a way to increase cultural knowledge. This notion is supported in the current findings given the positive correlation between Networking and MOS. Thus, Networking goes beyond social affiliation, as assessed in many acculturation measures, and describes the nature of the interaction, which, in this case, is to establish connections in the environment.

Family Relationships as a factor of intercultural competence is consistent with several Latino cultural values including familism, or the preference to maintain connected with family, and personalism, or the emphasis of maintaining smooth interpersonal relationships through warm, friendly, and personal interactions (Santiago-Rivera, Arredondo, \& Gallardo-Cooper, 2002). Strong family ties have been associated, in

Journal of Latina/o Psychology, Vol 1, No. 3 (August 2013): pg. 171-181. DOI. This article is @ American Psychological Association and permission has been granted for this version to appear in e-Publications@Marquette. American Psychological Association does not grant permission for this article to be further copied/distributed or hosted elsewhere without the express permission from American Psychological Association. 
a reciprocal fashion, with competence behaviors that, in turn, foster close and intimate relationships (Carlo \& de Guzman, 2009). The quality of interactions with family and friends is a vital aspect of navigating in multiple cultures perhaps to function as sources of support. Maintaining the Traditional Culture is an aspect of intercultural competence that emphasizes the value of cultural traditions and can provide a frame of reference for dealing with cultural pressures. This factor also suggests that identifying and embracing the Latino culture is key to success within the traditional context.

As a limitation to the current project, the development of the MICS and subsequent factor structure was based in large part by the qualitative study reported by Torres (2009) which, although appropriate and necessary when examining a new construct, may have restricted the generation of scale items and/or the inclusion of additional factors. This is particularly important to note given the relatively small samples used in the Torres study. On the other hand, focusing on participant-derived themes and items, rather than researcher-derived, provides a grassroots understanding of the construct and taps into the general shared knowledge within the community. The generalizability of this scale is limited to individuals of Mexican descent and not Latinos overall. It is believed that the process of intercultural competence will apply across ethnic groups but that the cultural content may vary (Tyler, 2001). Future research seeking to expand and validate the MICS to other Latino sub-groups will need to incorporate several steps. First, qualitative interviews of non-Mexican Latinos can examine the attributes that parallel the current taxonomy while adding characteristics unique to the particular ethnic group (e.g., Puerto Rican, Cuban, etc.). Second, the MICS along with items that emerge from each sub-group can be administered to larger samples for validity and reliability checks. Tests of measurement and structural invariance can then be conducted to determine if significant differences exist across Latino sub-groups.

Despite these limitations, this research project is one of few that have examined a competence-based formulation of cultural adaptation among a group of adults of Mexican descent. In terms of clinical implications, the findings suggest that Mexican intercultural competence provides a frame of reference by which to identify 
protective and resilience factors. Practically, clinicians can use the MICS as an indicator of a client's cultural strengths and discuss how they match or correspond to critical life domains. Interventions can focus on strengthening current skills and/or building on other areas of competence. For instance, helping clients develop realistic goals and expectations within the cultural rubric in which they reside can foster a sense of agency when negotiating cultures. Also, outlining network connections that assist goal attainment while nurturing relationships with family and friends as sources of support can prove to be extremely useful. The notion of intercultural competence can translate easily into culturally-appropriate interventions given that current conceptualizations of treatment focus on the implementation of active coping skills and behaviors (Hollon, Haman, \& Brown, 2002).

Theoretically, Mexican intercultural competence addresses the features that facilitate effectively navigating various cultural contexts, thus, building on previous acculturation research. As such, continued work should investigate the development of intercultural competence using longitudinal designs as well as the specific skills that serve to protect Latinos during challenging times. For instance, can intercultural competence serve to buffer an individual from the immediate negative psychological consequences of discrimination or is it more useful in abating the prolonged effects of this stressor? Finally, future research should also investigate the relationship between intercultural competence and mental health.

\section{Acknowledgments}

This research was supported in part by a grant from the National Institute of Mental Health (Torres, R21 MH077735).

\section{References}

Arbuckle JL, Wothke W. AMOS 4.0 User's guide. Chicago IL: Small waters corporation; 1999.

Bacallao ML, Smokowski PR. Entre dos mundos/between two worlds: Bicultural development in context. Journal of Primary Prevention. 2009;30:421-451.

Bauman S. The reliability and validity of the Brief Acculturation Rating Scale for Mexican Americans-II for children and adolescents. Hispanic Journal of Behavioral Sciences. 2005;27:426-441.

Journal of Latina/o Psychology, Vol 1, No. 3 (August 2013): pg. 171-181. DOI. This article is (C) American Psychological Association and permission has been granted for this version to appear in e-Publications@Marquette. American Psychological Association does not grant permission for this article to be further copied/distributed or hosted elsewhere without the express permission from American Psychological Association. 
NOT THE PUBLISHED VERSION; this is the author's final, peer-reviewed manuscript. The published version may be

accessed by following the link in the citation at the bottom of the page.

Benet-Martinez V, Haritatos J. Bicultural identity integration (BII): Components and psychosocial antecedents. Journal of Personality. 2005;73:1015-1049.

Carlo G, de Guzman MRT. Theories and research on prosocial competencies among U.S. Latinos/as. In: Villarruel FA, Carlo G, Grau JM, Azmitia M, Cabrera NJ, Chahin TJ, editors. Handbook of US Latino psychology: Developmental and community-based perspectives. Thousand Oaks, CA: Sage Pubications; 2009. pp. 191-212.

Cuellar I, Bastida E, Braccio SM. Residency in the United States, subjective well-being, and depression in an older Mexican-origin sample. Journal of Aging and Health. 2004;16:447-466.

David EJR, Okazaki S, Saw A. Bicultural self-efficacy among college students: Initial scale development and mental health correlates. Journal of Counseling Psychology. 2009;56:211-226.

Dressler WW, Balieiro MC, dos Santos JE. Culture, socioeconomic status, and physical and mental health in Brazil. Medical Anthropology Quarterly. $1998 ; 12: 424-446$.

Hollon SD, Haman KL, Brown LL. Cognitive-behavioral treatment for depression. In: Gotlib IH, Hamen CL, editors. Handbook of Depression. New York: Guilford Press; 2002. pp. 383-403.

Hong Y-y, Morris MW, Chiu C-y, Benet-Martinez V. Multicultural minds: A dynamic constructivist approach to culture and cognition. American Psychologist. 2000;55:709-720.

Hu L, Bentler PM. Cutoff criteria for fit indexes in covariance structure analysis: Conventional criteria versus new alternatives. Structural Equation Modeling. 1999;6:1-55.

Jensen LA. Bridging cultural and developmental approaches to psychology: New syntheses in theory, research, and policy. New York: Oxford University Press; 2011.

Kasirye OC, Walsh JA, Romano PS, Beckett LA, Garcia JA, Elvine-Kreis B, Bethel JW, Schenker MB. Acculturation and its association with healthrisk behaviors in a rural Latina population. Ethnicity and Disease. 2005; 15:733-739.

LaFromboise T, Coleman HLK, Gerton J. Psychological impact of biculturalism: Evidence and theory. Psychological Bulletin. 1993;114:395-412.

Masten AS, Curtis WJ. Integrating competence and psychopathology: Pathways toward a comprehensive science of adaptation in development. Development and Psychopathology. 2000;12:529-550.

McDonald R, Ho MR. Principles and practices in reporting structural equation analyses. Psychological Methods. 2002;7:64-82.

Mistry J, Wu J. Navigating cultural worlds and negotiating identities: A conceptual model. Human Development. 2010;53:5-25.

Journal of Latina/o Psychology, Vol 1, No. 3 (August 2013): pg. 171-181. DOI. This article is (C) American Psychological Association and permission has been granted for this version to appear in e-Publications@Marquette. American Psychological Association does not grant permission for this article to be further copied/distributed or hosted elsewhere without the express permission from American Psychological Association. 
NOT THE PUBLISHED VERSION; this is the author's final, peer-reviewed manuscript. The published version may be accessed by following the link in the citation at the bottom of the page.

Ogbu J. Origins of human competence: A cultural-ecological perspective. Child Development. 1981;52:413-429.

Padilla AM. Bicultural social development. Hispanic Journal of Behavioral Sciences. 2006;28:467-497.

Padilla AM, Perez W. Acculturation, social identity, and social cognition: A new perspective. Hispanic Journal of Behavioral Sciences. 2003;25:35-55.

Pew Hispanic Center. The 10 largest Hispanic origin groups: Characteristics, rankings, top counties. Washington, D.C: Pew Hispanic Center; 2012.

Santiago-Rivera AL, Arredondo P, Gallardo-Cooper M. Counseling Latinos and la familia: A practical guide. Thousand Oaks, CA: Sage Publications; 2002.

Schwartz SJ, Unger JB, Zamboanga BL, Szapocznik J. Rethinking the concept of acculturation: Implications for theory and research. American Psychologist. 2010;65:237-251.

Spitzberg BH, Changnon G. Conceptualizing intercultural competence. In: Deardorff DK, editor. The SAGE Handbook of Intercultural Competence. Thousand Oaks, CA: SAGE Publications; 2009. pp. 2-52. Tabachnick BG, Fidell LS. Using multivariate statistics. 5. New York: Harper Collins; 2007.

Torres L. Latino definitions of success: A cultural model of intercultural competence. Hispanic Journal of Behavioral Sciences. 2009;31:576593.

Tyler FB. Individual psychosocial competence: A personality configuration. Educational and Psychological Measurement. 1978;38:309-323.

Tyler FB. Cultures, communities, competence, and change. New York: Plenum Publishers; 2001.

U.S. Bureau of the Census. The American community - Hispanics: 2004 (No ACS-03) Washington, DC: U.S. Department of Commerce; 2007.

Ullman JB. Structural equation modeling. In: Tabachnick B, Fidell L, editors. Using multivariate statistics. 3. New York: Harper Collins; 1996. pp. 709-812.

Wei M, Liao KYH, Chao RCL, Mallinckrodt B, Tsai PC, Botello-Zamarron R. Minority stress, perceived bicultural competence, and depressive symptoms among ethnic minority college students. Journal of Counseling Psychology. 2010;57:411-422.

Zea MC, Reisen CA, Tyler FB. Reliability, ethnic comparability, and validity evidence for a condensed measure of proactive coping: The BAPC-C. Educational and Psychological Measurement. 1996;56:330-343.

Journal of Latina/o Psychology, Vol 1, No. 3 (August 2013): pg. 171-181. DOI. This article is (C) American Psychological Association and permission has been granted for this version to appear in e-Publications@Marquette. American Psychological Association does not grant permission for this article to be further copied/distributed or hosted elsewhere without the express permission from American Psychological Association. 